\title{
Harry Potter and the Osteopathic Medical School Part 2: Creating a Virtual Harry Potter-Themed Day as a High-Yield Review for Final Examinations
}

\author{
Taylor Willis $^{1} \cdot$ Victoria Bryant ${ }^{1}$ (D)
}

Accepted: 30 December 2021 / Published online: 11 January 2022

(c) The Author(s) under exclusive licence to International Association of Medical Science Educators 2022

\begin{abstract}
The role of gamification and active learning has been common topics of conversation in higher education for many years. These learning tools have been correlated with a multitude of positive effects, including increased student engagement, collaboration, and motivation to learn. This article explores the role of gamification and active learning in a virtual setting using a gamified Harry Potter-themed final examination review session for first-year osteopathic medical students. We also discuss how gamification can be used to improve the connectivity and wellness of students as they attend classes almost entirely online during the COVID-19 global pandemic.
\end{abstract}

Keywords Harry Potter · Gamification · Wellness activities $\cdot$ Virtual medical education · Active learning $\cdot$ Examination preparation and reviews

\section{Background}

Discussions of gamification and active learning, along with their implications in higher education, have been growing rapidly over the past decade [1]. Gamification refers to the application of game design elements in non-game contexts and in recent years has been used to engage students in the learning process [2]. It is an important supplement to the traditional lecture-style teaching because it has the potential to improve productivity, student engagement, collaboration, motivation to learn, and real-world application [3-6]. Research has also shown gamification's significance in providing social connectivity among students [7], which has become increasingly important as many schools have temporarily shifted their curriculum online in light of the COVID-19 pandemic.

Given the desire for non-traditional learning methods and the benefits that active learning and gamification have the potential to produce $[5,6,8]$, our medical school has been incorporating such methodologies into our curriculum for

Victoria Bryant

victoriabryant@atsu.edu

1 A. T. Still University School of Osteopathic Medicine in Arizona, 5850 E. Still Circle, Mesa, AZ 85206, USA the last three years. We previously reported a Harry Potterthemed didactic examination review event for our first-year osteopathic medical students [9]. The format of this event consisted of discipline-specific Harry Potter-themed classrooms, as well as wellness-inspired events, such as a sorting hat ceremony, a trivia contest, and a quidditch tournament. This year, we made some changes to accommodate for the COVID-19 guidelines, and the event was held online. Because of the virtual nature of the event, we took advantage of the technology available and implemented several new gamification strategies discussed herein. And, because the students could only interact with each other online during this academic year, we decided to focus on increasing connectivity and wellness among the student body.

\section{Activity}

Participation in the Harry Potter-themed activities and reviews was non-mandatory and limited to first-year osteopathic medical students. The first activity was a virtual sorting ceremony in which students were placed into one of four Hogwarts Houses (Gryffindor, Hufflepuff, Ravenclaw, or Slytherin) by a faculty member dressed as Professor Albus Dumbledore (headmaster of Hogwarts School of Witchcraft and Wizardry). The next activity was a Harry Potter trivia 
Table 1 Classroom Information: Attendance rates, average house points per student and number of lecture hours per discipline in the course

\begin{tabular}{|c|c|c|c|c|c|}
\hline Event & $\begin{array}{l}\text { No. of } \\
\text { students } \\
\text { attended }\end{array}$ & $\begin{array}{l}\text { Percentage of } \\
\text { students (out of } \\
160 \text { ) }\end{array}$ & $\begin{array}{l}\text { Percentage of } \\
\text { students (out of } \\
77 \text { ) }\end{array}$ & $\begin{array}{l}\text { Average House Points } \\
\text { gained per participating } \\
\text { student }\end{array}$ & $\begin{array}{l}\text { No. of NMSK } \\
\text { lecture hours per } \\
\text { discipline }\end{array}$ \\
\hline Potions (biochemistry) & 54 & $34 \%$ & $70 \%$ & 64 & 11 \\
\hline Physiology of Magic (physiology) & 52 & $33 \%$ & $68 \%$ & 32 & 21 \\
\hline Care of Magical Creatures (clinical) & 48 & $30 \%$ & $62 \%$ & 19 & 27 \\
\hline The Dark Arts (pathology) & 60 & $38 \%$ & $78 \%$ & 60 & 17 \\
\hline $\begin{array}{l}\text { Fantastic Bugs and Where to Find Them } \\
\text { (microbiology) }\end{array}$ & 52 & $33 \%$ & $68 \%$ & 43 & 12 \\
\hline $\begin{array}{l}\text { Defense Against the Dark Arts (immu- } \\
\text { nology) }\end{array}$ & 34 & $21 \%$ & $44 \%$ & 70 & 3.5 \\
\hline
\end{tabular}

contest, in which students participated in their respective house teams and competed against the other houses.

The main academic event was two days before the final examination for the neuromuscular/skeletal/senses (NMSK) block (the second academic block in our firstyear curriculum). There were six virtual Hogwarts-themed classrooms that were designed to review and test information for the upcoming final examination using gamification and active learning. Students earned house points as individuals or as teams of approximately 10 students. At the end of the event the three top scoring students received a prize from the student government association. Each virtual classroom had a one-hour zoom time slot which was run sequentially, so students could attend all the rooms if they wished to. The first room was Potions (biochemistry), in which students worked in zoom breakout room teams to answer a series of biochemistry questions using the Google Forms platform. Answering certain questions correctly earned the team a virtual "ingredient for polyjuice potion" (polyjuice is a potion in the Harry Potter series that allows the drinker to take on the appearance of a different person). Collecting all seven ingredients awarded the team an extra 30 house points each. Next was Physiology of Magic, in which the students worked in breakout room teams to answer physiology questions with a gamification twist. Some students had agreed to act as "Death eaters" (followers of the main villain in the books, Lord Voldemort) and attempted to sabotage their team by casting doubt and bringing the score down (refer to Online Resource 1 for full instructions). The Dark Arts (pathology) was a live quiz format using turning point technologies. Students worked individually to answer
Harry Potter-themed pathology questions and cases (refer to Online Resource 2 for examples), and certain questions earned them a "horcrux" (a receptacle for part of a person's soul). If they collected all seven horcruxes, they received a bonus 20 house points. Next was Care of Magical Creatures (clinical), in which participants were divided into four breakout rooms, each containing a clinical faculty member. Gamification was achieved by pairing students up for a "wizard duel," in which they were asked a clinical question, and the first student of the pair to answer correctly received house points. In the Fantastic Bugs and Where to Find Them (microbiology) room, students worked in breakout room teams to solve microbiology cases presented using Google Form links (see Online Resource 3 for examples). Finally, Defense Against the Dark Arts (immunology) used "taboo" style gamification. Working in three breakout room teams, each with a faculty member facilitator, a student clue-giver had two minutes to get their team to guess the immunology words privately chatted to that student by the facilitator, without saying the "unforgivable" (taboo) words (see Online Resource 4 for instructions and examples).

\section{Results and Discussion}

Because the event was non-mandatory, in contrast to previous years, students could choose which events and review sessions they wanted to attend, and therefore the number of students who participated in each individual event was variable (see Table 1 and Online Resource 5). A total of 23 out of the 160 students in the class (14\%) attended the sorting

Table 2 Student survey results for wellness and connectivity

\begin{tabular}{|c|c|c|c|c|c|}
\hline Student Survey Questions & Strongly agree & Agree & Neutral & Disagree & Strongly disagree \\
\hline I felt more connected to the faculty & $54 \%(\mathrm{~N}=14)$ & $27 \%(\mathrm{~N}=7)$ & $15 \%(\mathrm{~N}=4)$ & $4 \%(\mathrm{~N}=1)$ & $0 \%(\mathrm{~N}=0)$ \\
\hline I felt more connected to the other students & $33 \%(\mathrm{~N}=9)$ & $44 \%(\mathrm{~N}=12)$ & $15 \%(\mathrm{~N}=4)$ & $7 \%(\mathrm{~N}=2)$ & $0 \%(\mathrm{~N}=0)$ \\
\hline I felt a decrease in my stress level & $30 \%(\mathrm{~N}=8)$ & $44 \%(\mathrm{~N}=12)$ & $15 \%(\mathrm{~N}=4)$ & $11 \%(\mathrm{~N}=3)$ & $0 \%(\mathrm{~N}=0)$ \\
\hline
\end{tabular}


Table 3 Student Survey Results of Individual Classrooms

\begin{tabular}{|c|c|c|c|c|c|c|}
\hline Classrooms & Survey Questions & Strongly agree & Agree & Neutral & Disagree & Strongly disagree \\
\hline \multirow[t]{4}{*}{ Care of Magical Creatures (clinical) } & It was an enjoyable experience & $\begin{array}{l}42 \% \\
(\mathrm{~N}=10)\end{array}$ & $\begin{array}{l}38 \% \\
(\mathrm{~N}=9)\end{array}$ & $\begin{array}{l}17 \% \\
(\mathrm{~N}=4)\end{array}$ & $\begin{array}{l}4 \% \\
(\mathrm{~N}=1)\end{array}$ & $\begin{array}{l}0 \% \\
(\mathrm{~N}=0)\end{array}$ \\
\hline & $\begin{array}{l}\text { The academic content was } \\
\text { appropriate }\end{array}$ & $\begin{array}{l}54 \% \\
(\mathrm{~N}=13)\end{array}$ & $\begin{array}{l}38 \% \\
(\mathrm{~N}=9)\end{array}$ & $\begin{array}{l}8 \% \\
(\mathrm{~N}=2)\end{array}$ & $\begin{array}{l}0 \% \\
(\mathrm{~N}=0)\end{array}$ & $\begin{array}{l}0 \% \\
(\mathrm{~N}=0)\end{array}$ \\
\hline & It was creative & $\begin{array}{l}50 \% \\
(\mathrm{~N}=12)\end{array}$ & $\begin{array}{l}38 \% \\
(\mathrm{~N}=9)\end{array}$ & $\begin{array}{l}4 \% \\
(\mathrm{~N}=1)\end{array}$ & $\begin{array}{l}8 \% \\
(\mathrm{~N}=2)\end{array}$ & $\begin{array}{l}0 \% \\
(\mathrm{~N}=0)\end{array}$ \\
\hline & It utilized active learning & $\begin{array}{l}46 \% \\
(\mathrm{~N}=11)\end{array}$ & $\begin{array}{l}46 \% \\
(\mathrm{~N}=11)\end{array}$ & $\begin{array}{l}8 \% \\
(\mathrm{~N}=2)\end{array}$ & $\begin{array}{l}0 \% \\
(\mathrm{~N}=0)\end{array}$ & $\begin{array}{l}0 \% \\
(\mathrm{~N}=0)\end{array}$ \\
\hline \multirow[t]{4}{*}{$\begin{array}{l}\text { Fantastic Bugs and Where to Find } \\
\text { Them (microbiology) }\end{array}$} & It was an enjoyable experience & $\begin{array}{l}48 \% \\
(\mathrm{~N}=11)\end{array}$ & $\begin{array}{l}52 \% \\
(\mathrm{~N}=12)\end{array}$ & $\begin{array}{l}0 \% \\
(\mathrm{~N}=0)\end{array}$ & $\begin{array}{l}0 \% \\
(\mathrm{~N}=0)\end{array}$ & $\begin{array}{l}0 \% \\
(\mathrm{~N}=0)\end{array}$ \\
\hline & $\begin{array}{l}\text { The academic content was } \\
\text { appropriate }\end{array}$ & $\begin{array}{l}52 \% \\
(\mathrm{~N}=12)\end{array}$ & $\begin{array}{l}48 \% \\
(\mathrm{~N}=11)\end{array}$ & $\begin{array}{l}0 \% \\
(\mathrm{~N}=0)\end{array}$ & $\begin{array}{l}0 \% \\
(\mathrm{~N}=0)\end{array}$ & $\begin{array}{l}0 \% \\
(\mathrm{~N}=0)\end{array}$ \\
\hline & It was creative & $\begin{array}{l}48 \% \\
(\mathrm{~N}=11)\end{array}$ & $\begin{array}{l}48 \% \\
(\mathrm{~N}=11)\end{array}$ & $\begin{array}{l}4 \% \\
(\mathrm{~N}=1)\end{array}$ & $\begin{array}{l}0 \% \\
(\mathrm{~N}=0)\end{array}$ & $\begin{array}{l}0 \% \\
(\mathrm{~N}=0)\end{array}$ \\
\hline & It utilized active learning & $\begin{array}{l}48 \% \\
(\mathrm{~N}=11)\end{array}$ & $\begin{array}{l}48 \% \\
(\mathrm{~N}=11)\end{array}$ & $\begin{array}{l}4 \% \\
(\mathrm{~N}=1)\end{array}$ & $\begin{array}{l}0 \% \\
(\mathrm{~N}=0)\end{array}$ & $\begin{array}{l}0 \% \\
(\mathrm{~N}=0)\end{array}$ \\
\hline \multirow[t]{4}{*}{ Physiology of Magic (physiology) } & It was an enjoyable experience & $\begin{array}{l}58 \% \\
(\mathrm{~N}=11)\end{array}$ & $\begin{array}{l}37 \% \\
(\mathrm{~N}=7)\end{array}$ & $\begin{array}{l}0 \% \\
(\mathrm{~N}=0)\end{array}$ & $\begin{array}{l}5 \% \\
(\mathrm{~N}=1)\end{array}$ & $\begin{array}{l}0 \% \\
(\mathrm{~N}=0)\end{array}$ \\
\hline & $\begin{array}{l}\text { The academic content was } \\
\text { appropriate }\end{array}$ & $\begin{array}{l}53 \% \\
(\mathrm{~N}=10)\end{array}$ & $\begin{array}{l}42 \% \\
(\mathrm{~N}=8)\end{array}$ & $\begin{array}{l}0 \% \\
(\mathrm{~N}=0)\end{array}$ & $\begin{array}{l}5 \% \\
(\mathrm{~N}=1)\end{array}$ & $\begin{array}{l}0 \% \\
(\mathrm{~N}=0)\end{array}$ \\
\hline & It was creative & $\begin{array}{l}53 \% \\
(\mathrm{~N}=10)\end{array}$ & $\begin{array}{l}42 \% \\
(\mathrm{~N}=8)\end{array}$ & $\begin{array}{l}0 \% \\
(\mathrm{~N}=0)\end{array}$ & $\begin{array}{l}5 \% \\
(\mathrm{~N}=1)\end{array}$ & $\begin{array}{l}0 \% \\
(\mathrm{~N}=0)\end{array}$ \\
\hline & It utilized active learning & $\begin{array}{l}63 \% \\
(\mathrm{~N}=12)\end{array}$ & $\begin{array}{l}32 \% \\
(\mathrm{~N}=6)\end{array}$ & $\begin{array}{l}5 \% \\
(\mathrm{~N}=1)\end{array}$ & $\begin{array}{l}0 \% \\
(\mathrm{~N}=0)\end{array}$ & $\begin{array}{l}0 \% \\
(\mathrm{~N}=0)\end{array}$ \\
\hline \multirow[t]{4}{*}{ The Dark Arts (pathology) } & It was an enjoyable experience & $\begin{array}{l}56 \% \\
(\mathrm{~N}=14)\end{array}$ & $\begin{array}{l}40 \% \\
(\mathrm{~N}=10)\end{array}$ & $\begin{array}{l}4 \% \\
(\mathrm{~N}=1)\end{array}$ & $\begin{array}{l}0 \% \\
(\mathrm{~N}=0)\end{array}$ & $\begin{array}{l}0 \% \\
(\mathrm{~N}=0)\end{array}$ \\
\hline & $\begin{array}{l}\text { The academic content was } \\
\text { appropriate }\end{array}$ & $\begin{array}{l}60 \% \\
(\mathrm{~N}=15)\end{array}$ & $\begin{array}{l}40 \% \\
(\mathrm{~N}=10)\end{array}$ & $\begin{array}{l}0 \% \\
(\mathrm{~N}=0)\end{array}$ & $\begin{array}{l}0 \% \\
(\mathrm{~N}=0)\end{array}$ & $\begin{array}{l}0 \% \\
(\mathrm{~N}=0)\end{array}$ \\
\hline & It was creative & $\begin{array}{l}64 \% \\
(\mathrm{~N}=16)\end{array}$ & $\begin{array}{l}32 \% \\
(\mathrm{~N}=8)\end{array}$ & $\begin{array}{l}4 \% \\
(\mathrm{~N}=1)\end{array}$ & $\begin{array}{l}0 \% \\
(\mathrm{~N}=0)\end{array}$ & $\begin{array}{l}0 \% \\
(\mathrm{~N}=0)\end{array}$ \\
\hline & It utilized active learning & $\begin{array}{l}68 \% \\
(\mathrm{~N}=17)\end{array}$ & $\begin{array}{l}28 \% \\
(\mathrm{~N}=7)\end{array}$ & $\begin{array}{l}4 \% \\
(\mathrm{~N}=1)\end{array}$ & $\begin{array}{l}0 \% \\
(\mathrm{~N}=0)\end{array}$ & $\begin{array}{l}0 \% \\
(\mathrm{~N}=0)\end{array}$ \\
\hline \multirow[t]{4}{*}{ Potions (biochemistry) } & It was an enjoyable experience & $\begin{array}{l}37 \% \\
(\mathrm{~N}=7)\end{array}$ & $\begin{array}{l}58 \% \\
(\mathrm{~N}=11)\end{array}$ & $\begin{array}{l}0 \% \\
(\mathrm{~N}=0)\end{array}$ & $\begin{array}{l}5 \% \\
(\mathrm{~N}=1)\end{array}$ & $\begin{array}{l}0 \% \\
(\mathrm{~N}=0)\end{array}$ \\
\hline & $\begin{array}{l}\text { The academic content was } \\
\text { appropriate }\end{array}$ & $\begin{array}{l}42 \% \\
(\mathrm{~N}=8)\end{array}$ & $\begin{array}{l}53 \% \\
(\mathrm{~N}=10)\end{array}$ & $\begin{array}{l}5 \% \\
(\mathrm{~N}=1)\end{array}$ & $\begin{array}{l}0 \% \\
(\mathrm{~N}=0)\end{array}$ & $\begin{array}{l}0 \% \\
(\mathrm{~N}=0)\end{array}$ \\
\hline & It was creative & $\begin{array}{l}37 \% \\
(\mathrm{~N}=7)\end{array}$ & $\begin{array}{l}47 \% \\
(N=9)\end{array}$ & $\begin{array}{l}16 \% \\
(\mathrm{~N}=3)\end{array}$ & $\begin{array}{l}0 \% \\
(\mathrm{~N}=0)\end{array}$ & $\begin{array}{l}0 \% \\
(\mathrm{~N}=0)\end{array}$ \\
\hline & It utilized active learning & $\begin{array}{l}47 \% \\
(\mathrm{~N}=9)\end{array}$ & $\begin{array}{l}53 \% \\
(\mathrm{~N}=10)\end{array}$ & $\begin{array}{l}0 \% \\
(\mathrm{~N}=0)\end{array}$ & $\begin{array}{l}0 \% \\
(\mathrm{~N}=0)\end{array}$ & $\begin{array}{l}0 \% \\
(\mathrm{~N}=0)\end{array}$ \\
\hline \multirow[t]{4}{*}{$\begin{array}{l}\text { Defense Against the Dark Arts } \\
\text { (immunology) }\end{array}$} & It was an enjoyable experience & $\begin{array}{l}53 \% \\
(\mathrm{~N}=8)\end{array}$ & $\begin{array}{l}13 \% \\
(\mathrm{~N}=2)\end{array}$ & $\begin{array}{l}13 \% \\
(\mathrm{~N}=2)\end{array}$ & $\begin{array}{l}13 \% \\
(\mathrm{~N}=2)\end{array}$ & $\begin{array}{l}7 \% \\
(\mathrm{~N}=1)\end{array}$ \\
\hline & $\begin{array}{l}\text { The academic content was } \\
\text { appropriate }\end{array}$ & $\begin{array}{l}40 \% \\
(\mathrm{~N}=6)\end{array}$ & $\begin{array}{l}13 \% \\
(\mathrm{~N}=2)\end{array}$ & $\begin{array}{l}27 \% \\
(\mathrm{~N}=4)\end{array}$ & $\begin{array}{l}13 \% \\
(\mathrm{~N}=2)\end{array}$ & $\begin{array}{l}7 \% \\
(\mathrm{~N}=1)\end{array}$ \\
\hline & It was creative & $\begin{array}{l}60 \% \\
(\mathrm{~N}=9)\end{array}$ & $\begin{array}{l}27 \% \\
(\mathrm{~N}=4)\end{array}$ & $\begin{array}{l}0 \% \\
(\mathrm{~N}=0)\end{array}$ & $\begin{array}{l}7 \% \\
(\mathrm{~N}=1)\end{array}$ & $\begin{array}{l}7 \% \\
(\mathrm{~N}=1)\end{array}$ \\
\hline & It utilized active learning & $\begin{array}{l}53 \% \\
(\mathrm{~N}=8)\end{array}$ & $\begin{array}{l}20 \% \\
(\mathrm{~N}=3)\end{array}$ & $\begin{array}{l}13 \% \\
(\mathrm{~N}=2)\end{array}$ & $\begin{array}{l}0 \% \\
(\mathrm{~N}=0)\end{array}$ & $\begin{array}{l}13 \% \\
(\mathrm{~N}=2)\end{array}$ \\
\hline
\end{tabular}

hat ceremony, 15 out of $160(9 \%)$ students attended the trivia activity, and 77 out of 160 (48\%) students participated in one or more of the Harry Potter-themed examination review sessions.
An IRB exempt anonymous survey was sent to only those students who actively participated in the event, and a separate anonymous survey was sent to the faculty hosting the classrooms. Of the 77 students that attended 
the event and received the survey, 26 completed the survey (34\% response rate), and the following data describe the responses those 26 students provided. In the first portion of the survey, $96 \%$ of students either agreed or strongly agreed that they enjoyed the Harry Potter theme of the events, and $85 \%$ either agreed or strongly agreed that carrying out the events virtually was effective (see Online Resource 6). The second part of the survey focused on student wellness and connectivity. Overall, $81 \%$ of students agreed or strongly agreed that they felt more connected to faculty, $77 \%$ agreed or strongly agreed that they felt more connected to other students, and $77 \%$ agreed or strongly agreed that their stress levels were reduced (see Table 2). Based on these results, we feel that we met our goals of conducting this event effectively virtually and of improving connectivity and wellness among the student body.

The final section of the survey asked students to evaluate each of the classrooms separately and rank the following statements from strongly agree to strongly disagree: "it was an enjoyable experience," "the academic content was appropriate," "it was creative," and "it utilized active learning." Overall, the performance of all the classrooms was very positive, as shown in Table 3. Based on the 3 written comments from the student survey, if we did this event again, we could have smaller team sizes and make minor improvements to a couple of the classrooms.

A separate faculty survey was sent to those who participated in the event, and five out of six responded. All either agreed or strongly agreed that they were able to incorporate active learning into their session, $80 \%$ agreed or strongly agreed that they had used gamification, and $80 \%$ agreed or strongly agreed that these learning tools were effective in the virtual setting (see Online Resource 7). The content of each review contained gamification elements, thus meeting our goal.

While our event was successful overall, there are a few limitations to address. This year's event was non-mandatory; therefore, the participation rate was lower at $48 \%$. We speculate that the students who attended might be biased for the theme or for review sessions in general. We also did not collect data on why students chose not to attend the event. Only 34\% of those that participated in the reviews completed the survey, and it is difficult to know whether the opinions of this sample size are representative of the whole. In addition, we would have liked to compare this year's event to the previous year in more detail, but this was difficult to do as the focus of this event was on the effectiveness of the virtual delivery, gamification and connectivity of participating students, issues that had not been addressed in the previous versions.

Overall, our results showed that gamification and active learning can be used successfully as a learning tool in a virtual setting and that it may help improve connectivity and wellness among students. Perhaps the significance of these results, especially in the context of the global pandemic we have all been living through, would best be interpreted by a quote from our favorite wizard, Albus Dumbledore: "Happiness can be found, even in the darkest of times, if only one remembers to turn on the light" [10].

Supplementary Information The online version contains supplementary material available at https://doi.org/10.1007/s40670-022-01501-4.

\section{References}

1. Varannai I, Sasvari P, Urbanovics A. The use of gamification in higher education: an empirical study. Int J Advan Comp Sci App. 2017;8(10).

2. Rutledge C, Walsh CM, Swinger N, Auerbach M, Castro D, Dewan M, Khattab M, Rake A, Harwayne-Gidansky I, Raymond TT, et al. Gamification in action: theoretical and practical considerations for medical educators. Acad Med. 2018;93(7):1014-20.

3. Brull S, Finlayson S. Importance of gamification in increasing learning. J Contin Educ Nurs. 2016;47(8):372-5.

4. Brull S, Finlayson S, Kostelec T, MacDonald R, Krenzischeck D. Using Gamification to improve productivity and increase knowledge retention during orientation. J Nurs Adm. 2017;47(9):448-53.

5. McCoy L, Lewis JH, Dalton D. Gamification and multimedia for medical education: a landscape review. J Am Osteopath Assoc. 2016;116(1):22-34.

6. Felszeghy S, Pasonen-Seppanen S, Koskela A, Nieminen P, Harkonen K, Paldanius KMA, Gabbouj S, Ketola K, Hiltunen M, Lundin $\mathrm{M}$, et al. Using online game-based platforms to improve student performance and engagement in histology teaching. BMC Med Educ. 2019;19(1):273.

7. Zainuddin Z, Chu S, Shujahat M, Perera C. The impact of gamification on learning and instruction: a systematic review of empirical evidence. Educ Res Rev 2020;30.

8. Kron FW, Gjerde CL, Sen A, Fetters MD. Medical student attitudes toward video games and related new media technologies in medical education. BMC Med Educ. 2010;10:50.

9. Bryant V. Harry Potter and the Osteopathic Medical School: creating a Harry Potter-Themed Day as a high-yield review for final exams. Med Sci Educ 2021:1-7.

10. Rowling JK. Harry Potter and the prisoner of Azkaban. New York: Arthur A. Levine Books; 1999.

Publisher's Note Springer Nature remains neutral with regard to jurisdictional claims in published maps and institutional affiliations. 